\title{
Fun, friends, and good p.r.: Celebrating National Library Week
}

\section{in an academic library}

\author{
By Candace R. Benefiel \\ Public Information Coordinator \\ Texas A $\cup M$ University
}

\author{
Johanne LaGrange \\ Cataloger \\ Columbia University
}

\author{
and Sandra da Conturbia \\ Documents Reference Librarian \\ Texas AdM University
}

\section{How Texas A\&M University makes an event out of National Library Week.}

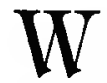

by should an academic library celebrate

National Library Week? For the same basic reasons an academic library uses other public relation activities: “To work toward an ever-greater awareness and use of the library by the campus 'family' and to help make the institution's library better known to those who support it."

\section{A history of the event}

National Library Week (NLW) has been enthusiastically observed by public and school libraries for over 30 years, but response to the annual event by academic libraries has been sporadic. Beginning in 1974, when the American Library Association took sole responsibility for the NLW public relations campaign from the National Book Committee, the scope of the program was expanded, "making it a year-round public relations program germane to all types of libraries."2 Regardless of these good intentions, however, in 1989 the ACRL Public Relations in Academic Libraries Discussion Group sponsored a presentation on NLW participation by academic libraries in order to stimulate interest in NLW by this sector of the library community. At this meeting of some 25 attendees, only a handful acknowledged that their respective libraries participated in observing NLW in any way. As the presenter at that meeting, Linda Wallace, director of the AI A Public Information Office, pointed out, "National Library Week is a ready-made promotional opportunity to support and enhance your local programs by tying in with the prestige of a national event." 3 She also noted that NLW materials can be adapted for any type of library. ${ }^{4}$

Once an academic library decides that some observance of NLW is appropriate, the task remains of determining what form the observance will take, and the nuts and bolts aspect of planning, organizing, and carrying out an event or series of events to mark the occasion. For such an observance to achieve maximum effectiveness, direction is necessary and should come from an overall view of the library's needs and concerns.

The Sterling C. Evans Library at Texas A\&M University has celebrated NLW annually since 1975 , 
and has established a basic program of events planned and administered by a committee of library faculty and staff. The experience of the Evans Library with NLW provides an example of one method for an academic library to make good use of NLW as a promotional opportunity.

\section{How one library celebrates}

In 1975 the Evans Library took the important step of instituting NLW celebrations on the Texas A\&M University campus. A three-person committee was selected to plan and coordinate events for that first year, which included an open forum on library concerns and policies, a display of craft items made by library staff, an informal outdoor concert, a speaker from NASA, and a booksale sponsored by the Friends of the SterlingC. Evans Library. The week was busy, and highly successtul, on a budget of about $\$ 250$.

Since that first NLW at the Evans Library, more than 15 annual celebrations have come and gone. Over the years, various activities have been tried and either continued or discarded. The NLWCommittee is now a major subcommittee of the Committee on Library Planning and Programs, and has eight appointed members, and last year expenditures were ahout $\$ 1,700$. Fxpenses are paid with money generated by the booksale from the previous year.

\section{The possible activities are endless}

Some of the activities that have been used at the Evans Library as a part of NLW celebrations are: poetry readings, usually of student work; video/ movie showings (discontinued due to copyright considerations); panel discussions, featuring invited speakers; auctions by sealed bid of major items donated for the booksale; awards by the library to faculty members displaying outstanding support of the library; dramatic presentations by student theater groups; folk dancers; and receptions honoring library benefactors and new collections.

Current activities for NLW at the Evans Library include: presentation of library employee longevity awards, an NLW tradition since 1985; presentation of the Davis Library Opportunity Scholarships, begun in 1987; a featured speaker; and the Friends of the Library Booksale, which provides funds for the other activities.

\section{How to plan}

In 1991, as for previous years, a member elected to the Committee on Library Planning and Programs served as chair of the NLW Committee, and selected and recruited a committee of seven library faculty and staff. Those seven are responsible for: promotion and public relations, scholarships, booksale, speakers, graphics, receptions, and displays. As well as individual duties, the committee members as agroup are responsible for selecting and approving a theme, usually with input from the library director.

In addition, the current chair of the Committee on Library Planning and Programs handles arrangements for the Library Longevity Awards. The Longevity Awards ceremony has been, since 1987,

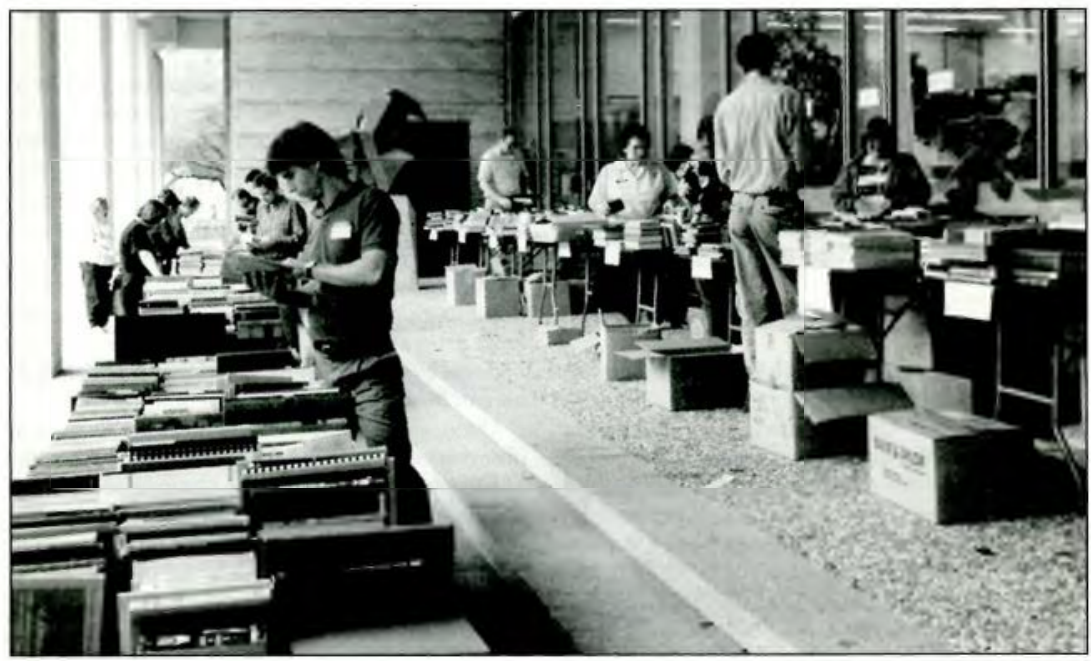

The Friends of the Sterling C. Evans Library Booksale at Texas A\&M University annually attracts readers from across campus and beyond. 
combined with the student worker scholarship presentation. Employees who have been at the library for ten, 15, 20, 25 (and so on) years are presented with a framed certificate and a gift. After the presentations, one of the longevity award recipients makes a short, frequently humorous, statement of acceptance on behalf of all the longevity awardees. This speech often takes the form of reminiscences on how things have changed or strange occurrences witnessed in the library over the years.

\section{How to promote}

The responsibility for coordinating promotion of NLW is delegated to the library's public information coordinator. The public information coordinator works with the committee, and especially with the committee member in charge of graphics, to develop the theme for NLW, if the ALA theme is not adopted. The public information coordinator committee is done in concert with the public information coordinator and involves graphic design of flyers, posters, programs for events, and other materials. The graphics coordinator for 1991 , a member of the classified staff, designedalogo, plannedgraphics for programs to accompany the week's events, and also created otherdesigns to be used on flyers promoting NLW.

Displays, both inside and outside the library, are another way of effectively promoting NLW. Display cases may be used to illustrate library collections and services, and to advertise specific NLW activities. Use of display areas in the student
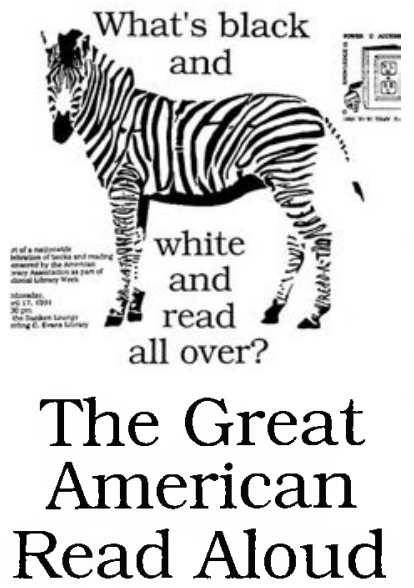

A promotional piece used by the Sterling C. Evans Library to encourage participation in National Library Week.

\section{Using featured speakers}

A featured speaker has often been the centerpiece of the Evans Library's NLW observances, and one committee member is detailed to oversee selection of a speaker based on input from the rest of the committee, the library director, and other interested parties. After the list is narrowed to two or three top choices, the speaker coordinator and the NLW chair correspond with and make arrangements for the speaker. Although the Evans Library has not been able to offer a large honorarium, committees in the past have found speakers of regional interest who were pleased to be asked to participate in promoting libraries. Speakers have ranged from novelists and journalists to scientists and consumer advocates.

In addition, as part of NLW 1991, the Evans Librarychose to participate in the Great American Read Aloud. This special event, staged on a nationwide scale, created the opunion building may appeal to students who do not use the library regularly. The display coordinator is responsible for reserving display cases, contacting library staff to prepare displays, and in some cases designing displays and assisting in their preparation.

The scholarship coordinator oversees the administration of awarding the Davis Library Opportunity Scholarships, an endowed fund which provides several scholarships for eligible student library workers, and for library staff who plan to pursue a career in librarianship. Administration of the scholarship program includes such duties as preparing and distributing application forms, selecting judges and coordinating the judging, and preparing and framing certificates for the award recipients.

The committee member in charge of the booksale portunity for each participating library to be a part of a larger community. To join in this event the Evans Library invited guests to read aloud. These were the featured speaker, local artist and writer Sunny Nash, campus volunteers, and several library staff members.

After each major activity, such as the speaker or the award ceremony, the NLW committee hosts an informal reception. The receptions are usually of the punch and cookies variety. The receptions coordinator is in charge of menus; arrangements, including flowers and decorations; and purchasing food and setting up the reception area. Since the budget for receptions is limited, this is a task which requires creativity and energy.

(Cont. on page 89) 
to the student newspaper and faculty publications. Provide radio and television public service advertise ments available through the ALA Graphics Catalog

Ed. note: The artwork on the cover of this month's CURL News is available as a poster from ALA Graphics. The poster is available separately or as part of the National Library Week theme kit that includes 3 posters, 200 bookmarks, and a campaign book including clip art. The kit sells for $\$ 25$ and may be ordered from ALA Graphics, $50 \mathrm{E}$. Huron St., Chicago, IL 60611; (800) 545-2433, press 8.

(NLW cont. from page 87)

\section{Planning is the key to success}

A successful NLW celebration does not just happen. As with so many other library activities, careful advance planning is a necessity. At the Evans Library, planning for NLW begins with the appointment of a new NLW Chair in May and committee selection follows as soon as possible. Planning meetings usually begin in late summer and continue, with increasing frequency, until the event.

Although the NLW Committee does not work from a set of guidelines, reports of former committees provide a body of tradition to guide planning, and other advice and suggestions are passed on orally from committee to committee. NLW celebrations, however, should not be allowed to become static. Each year should bringnewideas and new approaches; each year should be a new experience.

Every library's observance of NLW is unique, as it should be, but the experiences of other libraries can offer ideas

Celebrating NLW takes time and effort, and requires a commitment on the part of the library as a whole. The rewards, however, can more than equal the effort. A successful NLW observance should heighten awareness of the library for both students and faculty, and can attract users from the non-university local community. NLW celebrations enhance the library's image and raise morale of the library staff. Activities which involve university faculty strengthen ties between the library and the faculty. An active and dynamic library will appear more attractive to potential donors of both funds and collections, and NLW activities can highlight the library's needs as well as its strengths. In addition, NLW activities can be structured to emphasize new library services.

Finally, once the direction has been decided, the planning completed, and the last-minute details taken care of, NLW celebrations can, and should, be fun for the library staff and patrons alike.

\section{NOTES}

'The National Library Week Program, Local Organization Handbookforthe National Library WeekProgram. (New York: The National Library Week Program, 1967), 48.

${ }^{2}$ Special \& Academic Library NLW Participation Sought," Library Joumal 102 (November 1, 1977): 2200 .

${ }^{3}$ Linda K. Wallace, "National Library Week: Are you kidding?" College \& Research Libraries News 50 (April 1989): 311-13.

${ }^{4}$ Ibid.

${ }^{5}$ Suzanne D. Gyeszly, "Book sale preparation for National Library Week," College \& Research Libraries News 51 (April 1990); 331-33.

\section{C $\downarrow R L$ News staff member has a winning idea}

Reggie Prim, C\&RL News editorial assistant, has a way with words. When ALA staff were asked by the Communications Department to think of slogans that conveyed Al_A's purpose to the general public, the ACRL staff went into action.

At ACRL's weekly staff brainstorming session, the staff generated a number of possible slogans. One of them was Reggie's suggestion, "The more you read the better we feel."

These were forwarded to ALA's Com- munications Department. While a final slogan has not been selected, Reggie's proposed slogan was so good that ALA's Graphics Department could not pass up the opportunity to produce a button.

White text on a green background, the buttons are available in bundles of 10 for $\$ 4.00$ plus $\$ 2.00$ for shipping and handling. Orders totalling less than $\$ 30$ must be prepaid. Send order to: ALA's Graphics Department, 50 E. Huron St., Chicago, IL 60611; fax (312) 440-9374. 